\title{
On the Construction of University Culture under the Background of Value Diversification
}

\author{
Xin Gao \\ Northeast Dianli University \\ Jilin City, Jilin Province, China, 132012
}

\begin{abstract}
In a multicultural society, the tendency of value diversification is inevitable. Value diversification is like a double-edged sword which brings opportunities as well as serious challenges to the higher education. Under such background, to find a good method to promote the construction of university culture is now pretty much the agenda for the educators as well as education administrators.
\end{abstract}

Keywords-value diversification; values; university culture; socialist core values

\section{UNIVERSITY CULTURE}

Culture is a social phenomenon. It is human being's long-term accumulation of experience and value throughout the history. Besides, culture has rich connotations which are divided by most scholars into generalized culture and culture in a narrow sense. The generalized culture is the sum of material and spiritual wealth in the human society. The culture in narrow sense refers to ideology and its corresponding superstructures. There is another classification of culture, that is, the material cultural, system cultural and spiritual cultural. To be specific, culture is both condensed in the materials and at the same time beyond the materials. It includes ideologies inherited by the human beings like history, literature, art, local customs and practices, manners, values as well as social systems etc.

University culture is the product of social development and higher education. It is formed with the university as the foundation. That is, it is formed among the campus environment yet not takes the form of material existence. It is formed throughout the long history of higher education and therefore reflects a university's teaching philosophy and tradition, school spirit of teaching and learning as well as its instructional objectives. As an important part composing socialist culture, the university is restricted by the socialist culture and its own law of development. "Debates among different schools of thoughts" bred the new knowledge and technologies. "Allowing different schools of thoughts to bloom," the university collects different social thoughts as well as amplifies all kinds of public opinions. In the university, different kinds of social thoughts collide with each other and get expressed through different ways. The university, unlike the secular culture, will examine and distinguish the good ones among them depending on the talents it cultivated.
Higher education is the top level of education. As the motto says: "The way of Great Learning lies in the enlightenment of brilliant virtues, the remolding of people, and the pursuit of ultimate goodness", higher education aims more than just to impart knowledge. More importantly, it ought to guide, edify and shape the best in the students. As the key area for creating knowledge, spreading culture and breeding the cultural mainstream, the university is the cradle of advanced culture. Therefore, in the process of talent cultivation, we should strengthen the construction of university culture so as to enhance the cultural soft power.

The nature of education is kind of cultural activity. And university culture, which is soul and blood of a university, determines the taste and student quality of the very university. The higher education in China has stepped into the popular stage while the cost of accessing knowledge has also decreased due to the advancement of information technology. And the speed of information update is amazingly fast. Under such background, the pure knowledge instillation can no longer meet the requirements of talent training which are brought by the new era. Therefore, we have to cultivate the advanced university culture and play full of its function of cultural education.

\section{CURRENT SituAtions FaCING UNIVERSITY CUlTURE-VAlUE DiversifiCATION}

As With the development of human society as well as the advancement of information technology, countries and nations in every corner of the world will inevitably be influenced by the tide of economic globalization. The economic globalization, at the same time, has brought great all-round changes to the human culture. Fierce collisions and amalgamation occurred between the tradition and the reality, the western and oriental cultures. The postmodernism culture in the west has driven the mass to hold in esteem the emotional value. No central consciousness and the plural value orientation have blurred the original standard of value judgments. China is currently in the period of deep reform of the economic system where the new concepts of "products", "competition", "profits" and "efficiency" present before people a completely fresh appearance. The traditional values are now faced with unprecedented impact brought by the changing social structure, making the thought activities of people increasingly more independently selective and divergent. The advent of picture-oriented era and 
consumption culture has substantially altered people's cognitive style and learning habit while at the same time guide and change people's value of ethics, consumption, aesthetics and sense of worth from all aspects regardless of their age, gender, social class and region. Therefore, value diversification has now become an iron fact under the background of cultural diversification.

The sense of worth is a concept in people's mind about value pursuit. It refers to people's basic ideas about the value of something and the criterion for judging things. One's sense of worth may guide his methods of value seeking. Once formed, such sense of worth will be relatively stable and enduring. At the stage of thought formation, college students form the group most easy to accept new ideas as well as most active in thought. As a branch of social culture, the culture of university forges the students' sense. In general, value diversification is like a double-edged sword which brings opportunities as well as serious challenges to the higher education.

\section{A、 Opportunities brought by value diversification to higher education}

Diversification is the trend of development for cultures in the modern society. Cultures from different regions, races as well as different systems collide and intermingle with each other, which is the manifestation of social progress. Values like co-existence, and inclusiveness or competition promoted the liberation of thought on our country as well as changed the value monism in the feudal society. From the perspective of value formation, value versification can broaden students' horizon and expand their value dimension. Through comparison, the students' resolving ability can be largely enhanced.

Value versification provides the individuals with more choices and attaches importance to students' individual development. Isel Berlin, a contemporary political economist in British said that: "All human beings need freedom and self-fulfillment. There is no single value and principle existing in the world without relation to human experience. Each value a person possesses has its own attributes which, at the same time, reflects the nature and characteristic of him. The real freedom lies in unencumbered choices." Value diversification makes the world get rid of the shackle of value monism and emphasizes the people's subjective consciousness. Therefore, living in a society of value versification, students may have more alternatives to choose from. They can thus develop themselves based on their individuality.

Value versification arouses people's enterprise and helps establish a positive life attitude. Before 1978, people's initiative was greatly eroded due to the equalitarianism advocated in the planned economy. They were accustomed to waiting and being asked to work. On the contrary, people's subjective consciousness was wakened. College students born after 1980s and 1990s are now featured with boldness, creativity and self-expression.

\section{$B$ 、 Challenges brought by value diversification to higher education}

Value diversification brings opportunities as well as serious challenges to the higher education. First of all, it may weaken peoples' traditional sense of worth. The Confucian ethics play an extremely important role in traditional Chinese culture, which are reflected in many good thoughts concerning the traditional Chinese philosophy, politics, history as well as education. For example, "The commander of the forces of a large state may be carried off, but the will of even a common man cannot be taken from him" and "Neither riches nor honors can corrupt him, not shaken or modified by one's poverty or destitution, not subdued by force" in Confucius emphasize the importance of "Benevolence", "righteousness", "courtesy", "wisdom" and "loyalty"; "Peace is precious" values the harmony in social life. "Faithfulness" of people is essential for a nation to be prosperous. There are also many thoughts concerning how to tackle the relation between human beings and the nature. For instance, "Letting the nature take their own course" in Zhuangzi; "Man can control the nature" in Xunzi; "Coordination between human beings and the nature" in the Book of Change. In general, these traditional values can be concluded as: putting public interests before one's own; putting others before oneself and even being selfless; coordinated development between human beings and the nature. However, being influenced by the market economy and numbers of western social thoughts, college students start to wander about such traditional values since the reform and opening up policy. Instead, they are prone to accept neoliberalism, postmodernism as well as pragmatism. Affected by the subjective consciousness, some students deem that others have no right to interfere their choice of value which is part of their freedom. Some of them even care naught for the social phenomena. The spirit and educational function which are special to universities, therefore, was gradually weakened, making the students' social responsibility was decreased.

Value diversification makes it harder for students to make judgment and choice. On one hand, students' sense of worth is still in the phase of formation. Despite of the fast speed of mental development, their mentality is not mature enough. Therefore, the students are prone to be affected by psychical conflicts and the instability of mental state. Living in an era of high speed, high-end technology and fierce competition, the college students are facing much stronger and complex psychological impact than in any other eras. On the other hand, due to lack of living experience and deep understanding of social system, social norms as well as social consciousness, college students are easily to feel at loss when entering into the society. They will inevitably wave between social value and individuality, between material and spirit, and between "loyalty" and "profit". Besides, they will lack a clear position on issues of patriotism and social affection. Such phenomenon, although very popular in any society, is especially true to students in China. That is possibly the result of the social reform and transformation in China. 


\section{BASIC STRATEGIES TO FUEL THE CONSTRUCTION OF UNIVERSITY CULTURE}

\section{A. Strengthen the education of traditional culture}

Chinese culture is long-standing without being outdated throughout China's 5000-year-history. The traditional Chinese culture is a strong impetus for achieving the great rejuvenation of the Chinese nation as well as a good resource universities can apply in talent cultivation. With the development of market economy and diversification of value orientation, it still shows extraordinary glamour. Wang Qishan, member of the Standing Committee of the Political Bureau of the CPC Central Committee, once pointed it out that: "The South Korean TV opera does have great influence on people in America and Europe. However, the essence and nature of it happen to accord with the traditional Chinese culture." Cultural inheritance is one of the tasks for university education. To strengthen the education of traditional Chinese culture, we should first cultivate our moral character. The traditional Chinese culture values selfperfection and the cultivation of one's moral sense, which is embodied in the mottos like "Every day I examine myself on three counts" in Confucius and "As heaven maintains vigor through movement, a gentleman should constantly strive for self-perfection" in the Book of Exchange. Therefore, we should cultivate the students' sense self-improvement so that the can bravely face the obstacles and overcome the difficulties. Secondly, we should promote vigorously collectiveness and the spirit of dedication so as to guide the students to take the social values as the criteria of selfevaluation. Thirdly, under the background of market economy, the temptation of money drives people to benefit themselves at the expense of others. Such behavior has greatly influenced the students. Hence, a complete code of ethics should be adopted in universities.

\section{B. Combine the foreign cultures with the traditional Chinese culture}

All the advanced cultural achievements are the common wealth of mankind of which openness is a typical feature. There is no culture that is immutable to changes. Therefore, a good university under the background of globalization should be formed through a mélange of different cultures at home and abroad. As to the foreign cultures, we should take their essence and discard the dregs. For the traditional Chinese culture, we should show our respect while not inherit it uncritically. Firstly, we should carefully comb the good and bad of the traditional Chinese culture. Then we can develop what is useful or healthy and discard what is not so as to ensure the inheritance of traditional culture. Moreover, we should combine the good foreign cultures with ours and make innovations out of them. Innovation is the holy mission the era has entrusted to the universities. On the road of cultural innovation, we should be extremely patient and base our strategies on the practice of construction of socialism with Chinese characteristics and make most use of the new media.

\section{Guide the cultural construction of university with the Socialist core values}

The mission of Chinese universities is to cultivate the talent successors for the cause of socialism with Chinese characteristics. Facing the collision and conflict of various cultures, the influence exerted by multiple social ethos as well as chaos in the field of ideology, universities should firmly grasp the orientation of advanced socialist culture and educate the students with the socialist core values. The socialist core values form the essence of advanced culture. These values control and dominate all other affairs in the construction of socialist culture. Therefore, universities should consolidate the guiding position of Marxism and firmly integrate the socialist core values into the whole process of university education. To achieve that, ideological and political theory education is an important vehicle. The students will know about the main task of the great cause of socialism through theoretical learning and therefore will increase their sense of identity to socialism with Chinese characteristics. Meanwhile, the task is not merely for courses of ideological and political theory. It should be carried out throughout all the links of education so that the socialist core values can be engraved on the students' mind. Besides, universities should guide the public opinion to a positive direction with socialist core values and construct a healthy and positive university culture where the mainstream values are strengthened.

\section{REFERENCES}

[1] Zhang Xiaofeng. Several questions worth noticing in the inheritance and innovation of university culture [J].Beijing Education, 2013(1).

[2] Gao Yanqing. On the ideological and political education guided by the system of socialist core values [J].Journal of Chinese Academy of Governance, 2012(11).

[3] Wang Zhixiu. Traditional culture education and modern talent training [J]. Journal of China Youth Political Studies, 2002(2). 